\title{
Genetically similar temperate phages form coalitions with their shared host that lead to niche-specific fitness effects
}

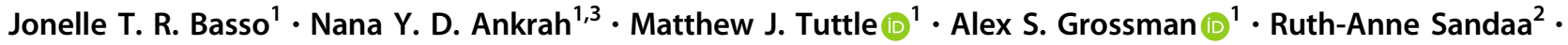 \\ Alison Buchan $\mathbb{1}^{1}$
}

Received: 20 September 2019 / Revised: 8 March 2020 / Accepted: 16 March 2020 / Published online: 2 April 2020

(c) The Author(s) 2020. This article is published with open access

\begin{abstract}
Temperate phages engage in long-term associations with their hosts that may lead to mutually beneficial interactions, of which the full extent is presently unknown. Here, we describe an environmentally relevant model system with a single host, a species of the Roseobacter clade of marine bacteria, and two genetically similar phages ( $\phi$-A and $\phi-D)$. Superinfection of a $\phi$-D lysogenized strain (CB-D) with $\phi$-A particles resulted in a lytic infection, prophage induction, and conversion of a subset of the host population, leading to isolation of a newly $\phi$-A lysogenized strain (CB-A). Phenotypic differences, predicted to result from divergent lysogenic-lytic switch mechanisms, are evident between these lysogens, with CB-A displaying a higher incidence of spontaneous induction. Doubling times of CB-D and CB-A in liquid culture are 75 and 100 min, respectively. As cell cultures enter stationary phase, CB-A viable counts are half of CB-D. Consistent with prior evidence that cell lysis enhances biofilm formation, CB-A produces twice as much biofilm biomass as CB-D. As strains are susceptible to infection by the opposing phage type, co-culture competitions were performed to test fitness effects. When grown planktonically, CB-A outcompeted CB-D three to one. Yet, during biofilm growth, CB-D outcompeted CB-A three to one. These results suggest that genetically similar phages can have divergent influence on the competitiveness of their shared hosts in distinct environmental niches, possibly due to a complex form of phage-mediated allelopathy. These findings have implications for enhanced understanding of the eco-evolutionary dynamics of host-phage interactions that are pervasive in all ecosystems.
\end{abstract}

\section{Introduction}

Temperate phages may engage in long-term association with their bacterial hosts that can lead to mutually beneficial interactions. It is well established that prophages can offer

Supplementary information The online version of this article (https:// doi.org/10.1038/s41396-020-0637-z) contains supplementary material, which is available to authorized users.

$\triangle$ Alison Buchan

abuchan@utk.edu

1 Department of Microbiology, University of Tennessee Knoxville, 1311 Cumberland Avenue, 307 Ken and Blaire Mossman Bldg., Knoxville, TN 37996, USA

2 Department of Biological Sciences, University of Bergen, PO 7803, N-5020 Bergen, Norway

3 Present address: Department of Entomology, Cornell University, 5136 Comstock Hall, Ithaca, NY 14853, USA their hosts benefits, including resistance to superinfection by homologous phages [1-4] and enhanced virulence through prophage-encoded toxins [e.g., 1, 5, 6]. However, the roles of prophages in enhancing both host and phage fitness are broadening in scope and complexity $[5,7]$.

Prophages have frequently been referred to as "time bombs" [e.g., 3], in which the nature of the host-phage relationship hinges upon the physiological status of the host. The most commonly cited trigger of prophage induction is damage of the host's DNA, typically the result of extrinsic factors such as UV radiation or chemical toxins, which induces a molecular cascade of events culminating in expression of prophage-encoded lytic genes [5, 8]. However, intrinsic factors may also promote activation of the lytic life cycle, a process termed spontaneous prophage induction (SPI) [6]. Even under seemingly optimal cultivation conditions, SPI occurs with low frequency in populations [range $0.09-3.1 \%$; 9-13]. SPI is often considered a detrimental process for the host as a fraction of cells is continuously lost by phage-mediated cell lysis. Yet, benefits 
of SPI on bacterial fitness have recently been recognized, including the release of extracellular DNA, which can be important for biofilm formation [6] and production of phages as weapons in competition with susceptible hosts [14].

Lysogeny is hypothesized to be prevalent in marine environments [15, 16], where approximately half of sequenced bacterial genomes contain prophage $[3,7]$. The abundance of marine temperate viruses is further supported by culture-independent approaches [17, 18]. Quantitative estimates of the prevalence of lysogeny in the ocean are principally derived from field-based mitomycin $\mathrm{C}$ induction experiments and vary widely, ranging from 0 to $71 \%$ [1921]. This observed variation is predicted to reflect environmental conditions (e.g., host productivity and abundance) that drive temperate phages into either a lysogenic or lytic state [19, 22-26] and has been the focus of recent debate (e.g., [27-29]). In contrast, a role for spontaneous induction has not been broadly considered in a marine context.

Roseobacters are abundant members of microbial assemblages in both planktonic and surface-associated marine niches [30-32] and prophages are common in genomes of cultured representatives [33, 34]. Thus, this environmentally relevant group of heterotrophic marine bacteria presents an opportunity to study host-phage interactions in the context of lysogeny. Sulfitobacter sp. strain CB2047 and its infecting temperate phage $\phi$-A were originally isolated from a phytoplankton bloom [35, 36]. Genome sequence analyses of the host revealed it was lysogenized with a prophage, denoted $\phi-\mathrm{D}$, that shares a high degree $(79 \%)$ of nucleotide identity with $\phi$-A [36]. Here, we report the complex interactions of this two-phage shared-host system.

\section{Methods}

\section{Bacterial growth, prophage induction, and infection}

Sulfitobacter sp. strain CB2047 (henceforth CB-D) was originally isolated from an Emiliania huxleyi phytoplankton bloom in Raunefjorden, Norway [36]. CB-D, and its derivative $\mathrm{CB}-\mathrm{A}$, were routinely grown at $25^{\circ} \mathrm{C}$ in the dark at $200 \mathrm{rpm}$ on Standard Marine Media (SMM), an artificial sea water medium supplemented with $0.11 \%$ yeast extract and $0.2 \%$ tryptone [37]. Phages were propagated by induction of exponentially growing lysogenic cultures with mitomycin C $(0.5 \mu \mathrm{g} / \mathrm{ml})$ following standard approaches [38]. Superinfections were performed by phage addition to early exponential phase cultures of permissive hosts $\left(\mathrm{OD}_{540 \mathrm{~nm}}=\right.$ 0.17 ) at a multiplicity of infection of 0.06 . These infections yield mixed phage populations due to concurrent induction of the resident prophage.

\section{Phage enumeration}

Phage abundance was monitored using plaque assay and quantitative PCR (qPCR). Plaque assays were performed on SMM using standard approaches [39]. qPCR assays used unique phage-specific primers (Table $\mathrm{S} 1$ ) and were performed with a DNA Engine Opticon 2 system with the Opticon Monitor 3.1.32 software package (Bio-Rad Laboratories, Inc., Hercules, CA). qPCRs were in $25 \mu \mathrm{L}$ reactions with $12.5 \mu \mathrm{L}$ SYBR Premix Ex Taq cocktail RR041 (Perfect Real Time; Takara Bio, Inc., Shiga, Japan), $500 \mathrm{nM}$ primers, and $10 \mu \mathrm{l}$ of phage DNA. Thermocycling conditions were as follows: $95^{\circ} \mathrm{C}$ for $2 \mathrm{~min}, 40$ cycles of $95^{\circ} \mathrm{C}$ for $20 \mathrm{~s}, 57^{\circ} \mathrm{C}$ for $20 \mathrm{~s}, 72^{\circ} \mathrm{C}$ for $20 \mathrm{~s}$, followed by $72{ }^{\circ} \mathrm{C}$ for $5 \mathrm{~min}$. Melt curves consistently showed single peaks per primer set, indicating high specificity. Standards were developed from plasmids containing cloned sequences and standard curves (correlation between log of gene copy numbers and $\mathrm{Ct}$ ) devised. Correlation coefficients for all standard curves were $\geq 0.99$.

\section{Gene expression assays}

Gene expression was quantified using quantitative reverse transcription-PCR (qRT-PCR) assays. Nucleic acids were extracted using AllPrep DNA/RNA Mini Kits (Qiagen, Valencia, CA) following manufacturer's instructions. After extraction of RNA, DNA was removed using the TURBO DNA-free Kit (Ambion, Austin, TX). The resulting RNA samples were converted to cDNA using M-MLV Reverse Transcriptase and random hexamers (Invitrogen, Carlsbad, CA) following manufacturer's instructions. M-MLV RT was heat inactivated by $15 \mathrm{~min}$ at $70^{\circ} \mathrm{C}$. qPCR was performed as described above.

Transcripts diagnostics of the host SOS response, phage DNA replication/repair, phage excision/cell lysis and prophage integration were quantified and normalized to the expression of three host reference genes (alaS, map, and rрoC) selected using previously described criteria [40]. Primers are shown in Table S1.

\section{Genome analysis}

Genomic DNA was isolated for both CB-A and CB-D using standard phenol/chloroform extraction procedures [41] and sequenced with the Illumina HiSeq platform at the Genomic Services Lab (HudsonAlpha Institute for Biotechnology, Huntsville, AL). Sulfitobacter sp. strain CB-D was resequenced to confirm the original sequence [36]. Genome reads were assembled using CLC Genomics Workbench version 7.5.1 (QIAGEN). Reads were independently mapped to the original CB-D genome sequence (JPOY00000000) using Map Reads to Reference, followed by Local Sequence 
Realignment. Average read coverage was 278 for CB-D and 292 for CB-A. The Fixed Ploidy Variant Detection tool was used to identify nucleotide differences between assembled genome contigs.

\section{Biofilm assays}

Clear flat-bottomed 96-well polypropylene plates (co-culture experiments) or $5 \mathrm{ml}$ polypropylene tubes (monoculture experiments) were inoculated with $100 \mu \mathrm{l}$ and $1 \mathrm{ml}$ of overnight cultures, respectively, grown in SMM (diluted in fresh medium to an $\mathrm{OD}_{540 \mathrm{~nm}}$ of $0.15-0.18 ; \sim 10^{7} \mathrm{CFU} / \mathrm{ml}$ ) and incubated at $25^{\circ} \mathrm{C}$. Relative biofilm formation of strains was quantified using a crystal violet assay and measured at OD $_{600 \mathrm{~nm}}$ using either a DU800 spectrophotometer (Beckman Coulter, Inc., CA) or a fluorescent plate reader (BioTek Instruments Inc, Vermont), as previously described [42].

\section{Co-culture competition assays}

Overnight monocultures of both lysogens were sub-cultured into fresh medium and grown to mid-log phase (ca. $1.0 \times$ $10^{8} \mathrm{CFU} / \mathrm{ml}$ ). Cells were harvested by gentle centrifugation $(5000 \times g$ for $10 \mathrm{~min})$, rinsed with fresh media to remove unbound phages and resuspended in fresh media. Lysogens were mixed at a ratio of $1: 1$ at an $\mathrm{OD}_{540}$ of $0.17\left(\sim 10^{7} \mathrm{CFU} /\right.$ $\mathrm{ml}$ ) and incubated at $25^{\circ} \mathrm{C}$, with shaking, for broth culture competition experiments. After $24 \mathrm{~h}$, samples were collected for: (1) genomic DNA extraction from bacteria and viruses; (2) viable counts; and (3) plaque assays. The relative abundance of each strain was determined using qPCR of genomic DNA isolated from mixed cellular biomass collected by centrifugation, following procedures outlined above. A caveat to the estimates of host abundance: the qPCR primers target genes within the prophage. As such, they do not distinguish between integrated and nonintegrated phage. Virus particles were enumerated from cell-free filtrate $(0.2 \mu \mathrm{m})$ as described above. Samples were first treated with Fermentas DNAse at $5 \mathrm{U} / \mathrm{ml}$ for $30 \mathrm{~min}$ at $37^{\circ} \mathrm{C}$ to destroy any free genomic DNA from lysed host cells. DNAase was heat inactivated by incubation of samples at $65^{\circ} \mathrm{C}$ for $10 \mathrm{~min}$. For qPCR of phages, samples were heated for $10 \mathrm{~min}$ at $95{ }^{\circ} \mathrm{C}$ and $2.5 \mu \mathrm{l}$ was used as template in $25 \mu \mathrm{l}$ reactions. Co-culture biofilm experiments were performed in a similar fashion with the following exceptions: $100 \mu$ l of 1:1 lysogen mixtures were added to individual wells of a 96-well microtiter dish and incubated at $25^{\circ} \mathrm{C}$ for $48 \mathrm{~h}$. qPCR was performed using extracted DNA from microbial biomass. Due to the adherent nature of the biofilm matrix, it was not possible to separate cells from the matrix which contains free-phage particles.

\section{Environmental virome data}

From the same induced E. huxleyi bloom from which CB$\mathrm{D}$ and $\phi$-A were isolated, a sample was collected immediately following collapse of the bloom for sequence characterization of viral particles. Details of the induced bloom are described in [43]; the sample analyzed for genetic analysis of the viral community was collected on day 15. Two liters of water were pre-filtered through a $1.2 \mu \mathrm{m}$ low-protein-binding Durapore membrane filter (Millipore Corp) and subsequently concentrated to a final volume of $\sim 50 \mathrm{ml}$ using a Vivaflow 200 benchtop system, with a $50 \mathrm{kDa}$ cut-off polyethersulfone membrane. Viruses were further concentrated by ultracentrifugation at $28,000 \mathrm{rpm}, 10^{\circ} \mathrm{C}$ for $2 \mathrm{~h}$. The viral pellet was dissolved in $200 \mu \mathrm{L}$ of SM buffer $\left(0.1 \mathrm{M} \mathrm{NaCl}, 8 \mathrm{mM} \mathrm{MgSO}_{4} \cdot 7 \mathrm{H}_{2} \mathrm{O}\right.$, $50 \mathrm{mM}$ Tris- $\mathrm{HCl}, 0.005 \%$ (w/v) glycerin). Lysis of the viral particles was performed in freshly made lysis buffer (250 mM EDTA pH 8.0, $1 \%$ SDS, $1 \mathrm{mg} / \mathrm{ml}$ Proteinase K). The agarose plugs were run at pulse-ramps at $8-30 \mathrm{~s}$ for $24 \mathrm{~h}$ at $14^{\circ} \mathrm{C}$ on a $1 \%$ w/v SeaKem GTG agarose (FMC, Rockland, Maine) gel in $1 \mathrm{X}$ TBE gel buffer using a BioRad DR-II CHEF Cell (Bio-Rad, Richmond, CA, USA) electrophoresis unit. Gels were visualized and digitized using the Fujifilm imaging system, LAS-3000, and 8 bands of interest (ranging in size from $\sim 35$ to $485 \mathrm{~kb}$ ) were excised. DNA was eluted from the PFGE agarose gel slices in 10,000 MWCO Spectra/Por, Regenerated Cellulose dialysis membranes (Spectrum Laboratories Inc. CA, USA) by electrophoresis in $1 \times$ TAE buffer $(40 \mathrm{mM}$ Tris-HCl, $1 \mathrm{mM}$ EDTA, $40 \mathrm{mM}$ acetic acid, $\mathrm{pH}$ 8.0) for $3 \mathrm{~h}$ at $70 \mathrm{~V}$. Further concentration of the DNA was performed using Vivaspin 500 columns (Milipore Corp) according to the manufacturer's protocol. Eluted DNA was amplified based on a linker-adapter PCR method using the WGA1 and Genome Plex WGA reamplification kit from Sigma (Sigma Aldrich, St Louis, MO, USA. Six separate WGA reactions were run and pooled before further processing. GenElute PCR Clean-Up Kit (Sigma Aldrich) was used for purification of the products that were then stored at $-80^{\circ} \mathrm{C}$ until sequencing at the Broad Institute under the Gordon and Betty Moore Foundation's Marine Phage, Virus, and Virome Sequencing Project.

\section{Statistical analysis}

RT-qPCR data analysis and the normalized relative transcript quantity were calculated using the qBASE method [44]. Student's $t$ tests were used to determine significant difference using GraphPad Prism (GraphPad Software, Inc.). 


\section{Nucleotide sequence accession numbers}

The genome sequence for Sulfitobacter sp. strain CB-A was deposited in GenBank under the accession number PYUG00000000. Genome sequences for $\phi-A$ and CB-D (with $\phi$-D within) were previously reported as HQ332142 and NC_027299, respectively [35, 36]. Size-selected virome libraries were previously deposited into the NCBI Short Read Archive (SRA; PRJNA47483). The two libraries referenced in this paper, $\sim 35 \mathrm{~kb}$ and $\sim 75 \mathrm{~kb}$ size fractions, are designated as ME-08-09 and ME-08-08, respectively, in the SRA.

\section{Results}

\section{Genome comparisons of temperate $\phi-A$ and prophage $\phi-D$ reveal high sequence similarity}

Within the genome of Sulfitobacter sp. CB-D lies the prophage $\phi-\mathrm{D}$, which is distinct from, yet highly similar to, $\phi$-A, a temperate virus isolated from the same waters as CB-D (Fig. 1). Genome-wide nucleotide similarity alignment of $\phi$-A and $\phi$-D show that they share an average of $79 \%$ identity, with the majority of the genomes nearly identical. A CoreGenesUniqueGenes [45] analysis identified 58 highly homologous genes (BLASTp threshold score, 75 ) between $\phi$-A and $\phi$-D. Both phages carry a suite of genes for phage structure, replication/host regulations, host integration/excision, lysis/structure, and share the same DNA Bre-C-like integrase anticipated to facilitate integration into the host genome [35, 36].

The sequence variation between $\phi$-A and $\phi$-D is localized to two 4-6 kb regions, which primarily encode genes of unknown function, but also includes putative tail fibers protein genes, expected to be important for binding to host cell-surface receptors, and transcriptional regulators that may repress lytic genes during lysogeny. The putative transcriptional regulators encoded within each phage have low sequence identity to one another: $<30 \%$ identity at amino acid level for all pairwise alignments. $\phi$-D harbors two ORFs (SUFP_003; SUFP_050) that fall within the XRE transcriptional regulator superfamily. Both contain an XREfamily HTH domain but lack the lexA/signal peptidase superfamily domain common to characterized phage repressors within this family. $\phi$-D also harbors an ORF (SUFP_063) with homology to the single stranded DNA binding protein family, with members involved in DNA replication via binding of ssDNA at the primosome assembly site. $\phi$-A possesses two ORFs that belong to the XRE-superfamily and lack specific catalytic domains (SUFA_030 and SUFA_031).
A temperate virus causes lytic infection and prophage induction

Infection of Sulfitobacter sp. CB-D with the temperate phage $\phi$-A results in prophage induction, production of both phage types and cell lysis. The growth dynamics of Sulfitobacter sp. CB-D cultures infected with $\phi$-A are indistinguishable from uninfected controls until the onset of cell lysis at $\sim 5 \mathrm{~h}$ post infection (h.p.i.), when significant differences in cultures are observed (Fig. 2a). By 10 h.p.i., optical densities in the infected cultures are $~ 40 \%$ of the uninfected controls and both phages are produced at unequal abundances (Fig. 2c). Infection of Sulfitobacter sp. CB-A with temperate phage $\phi$-D also results in prophage induction, production of both phage types and cell lysis, with an apparent decrease in the latent period ( 3 h.p.i.) relative to CB-D $\phi$-A superinfections (Fig. 2b, d). Using qPCR as a proxy for phage abundance, each of the superinfecting phages is present in at least tenfold higher abundance than the resident prophage 24 h.p.i. (Fig. 2c, d).

Quantitative RT-PCR of genes diagnostic for the host Sulfitobacter sp. strain CB-D, $\phi$-D, and $\phi$-A provide further evidence that a mixed lytic-lysogenic infection occurs. Expression of host genes indicative of the SOS response, recA and $l e x A$, as well as select phage genes involved in the presumptive lysogenic-lytic switch (XRE-type repressor [rep/XRE]), $\phi$-D phage DNA replication and repair (single stranded DNA binding protein gene $[s s b], \phi$-D double stranded DNA break repair gene [rad52]) and cell lysis (endolysin $[p e p G]$ ) were monitored at two discrete time points preceding and following measurable culture lysis (3 and 6 h.p.i., respectively) (Fig. 3). Consistent with the differences in phage production, the relative increase of $\phi$-A gene expression is greater than that observed for prophage $(\phi$-D) genes (Fig. 3b, c). The $\phi$-A XRE-type gene (SUAG_00031) is upregulated 66-fold 6h.p.i. compared with an 8-fold expression increase of the $\phi$-D $s s b$ gene (SUFP050) at the same time point (Fig. 3b, c). Similarly, endolysin gene expression (SUAG_00073) of the superinfecting phage $\phi$-A is upregulated 2700 -fold 6 h.p.i, while $\phi$-D endolysin gene expression (SUFP_019) is upregulated 44-fold at the same time point, relative to initial expression levels (Fig. 3b, c). Collectively, these data suggest both phages are actively employing lysogenic and lytic lifestyles that are likely influenced by the activities of the other.

\section{Generation of Sulfitobacter sp. strain CB-A}

Within the genome of CB-D, the $\phi$-D prophage is flanked by a 15 bp GC-rich direct terminal repeat (designated $a t t B$ ), within the $3^{\prime}$ end of a host tRNA-Leu gene (Fig. 1b), consistent with the observation that many phages and other 
(A)

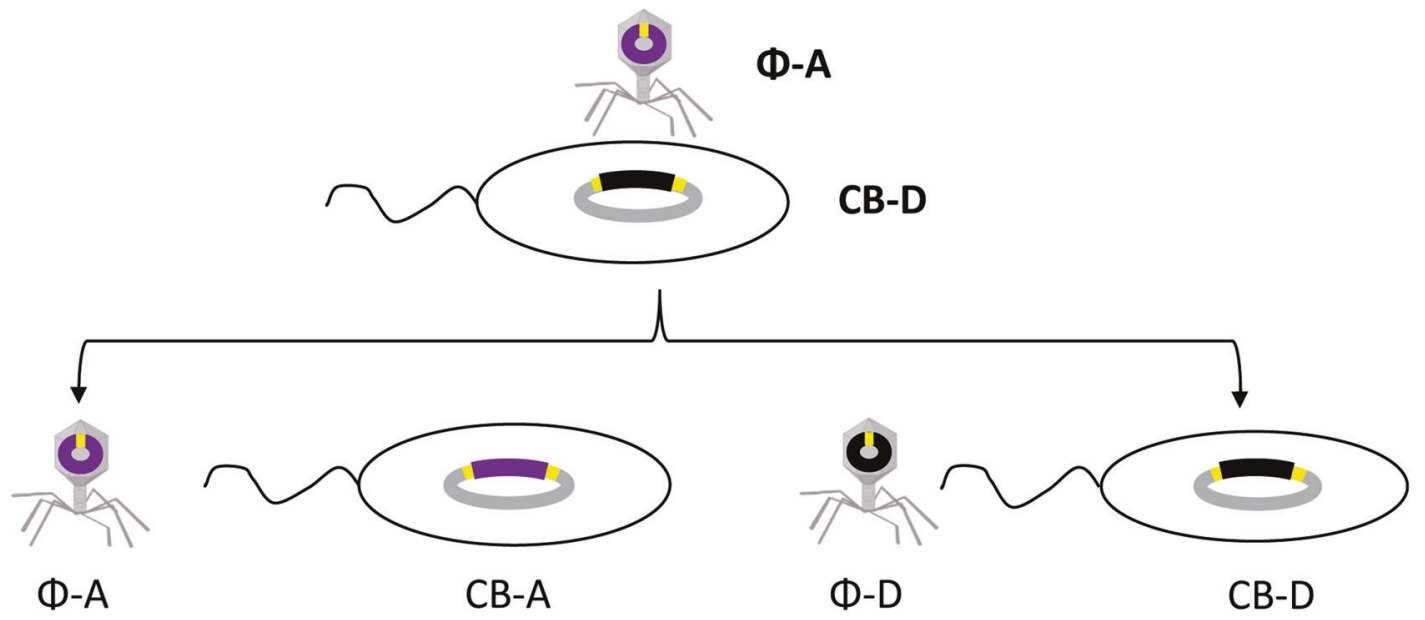

(B)

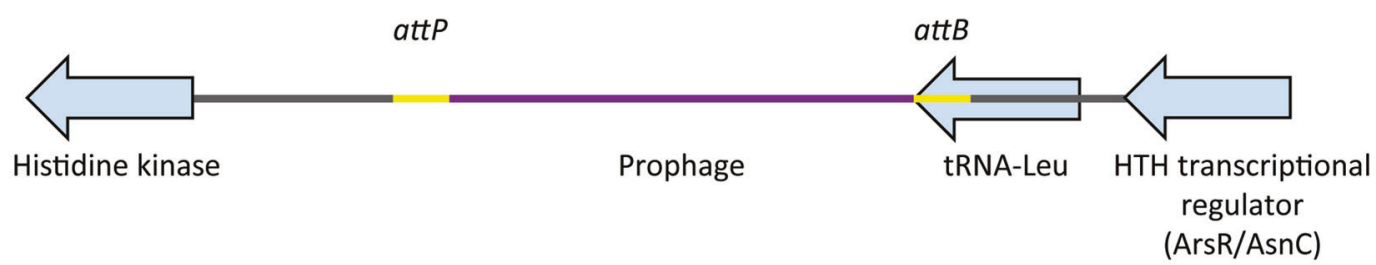

(C)
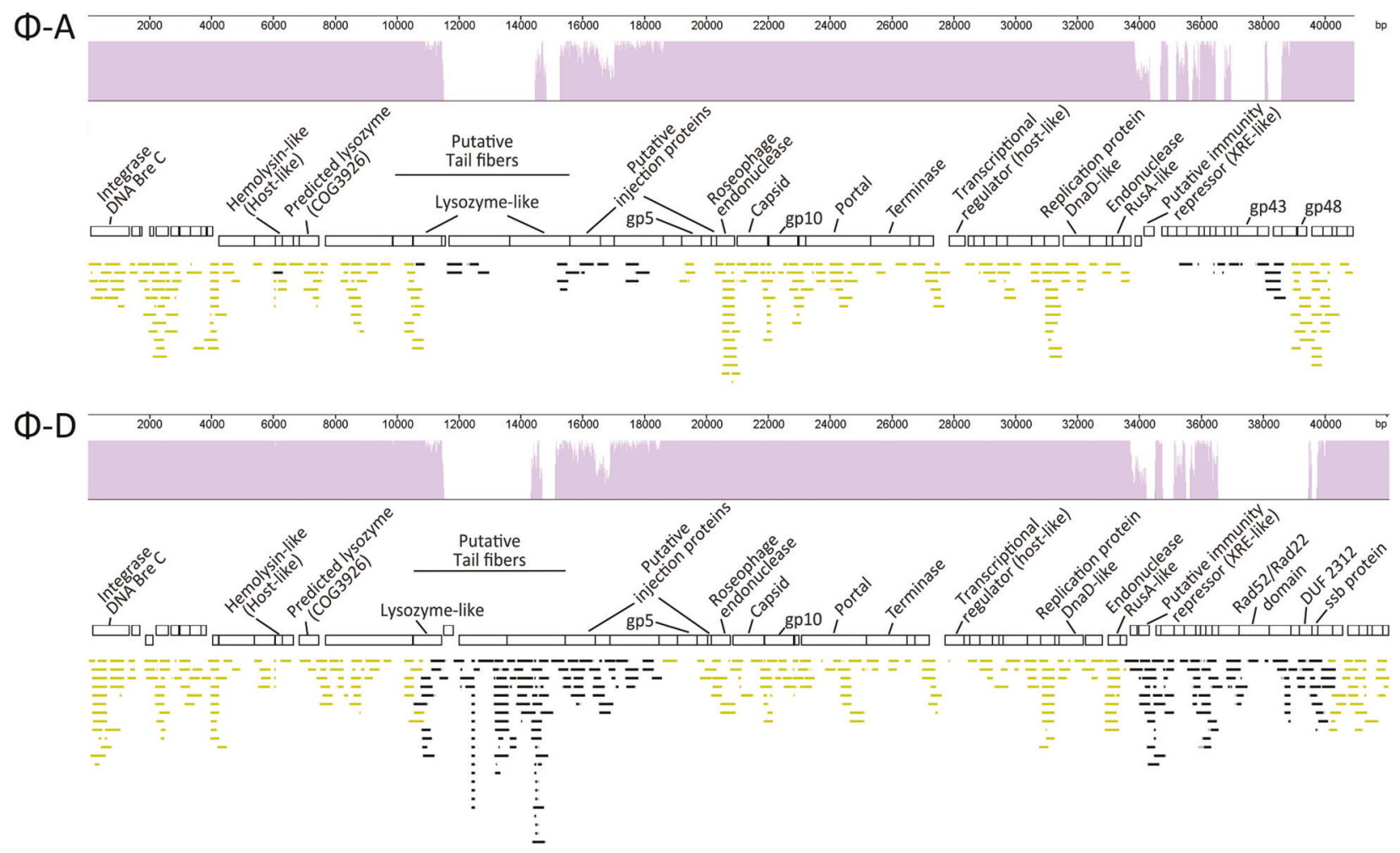

genetic elements have high affinity for integration into tRNA genes [46]. $\phi$-A harbors a single copy of this sequence, designated attP. Thus, we hypothesized that this putative attachment site could direct $\phi$-A viral DNA to the appropriate integration site in its host, generating a new lysogen. To test this hypothesis, a superinfection experiment was conducted using $\phi$-A and Sulfitobacter sp. strain CB-D. Four and $8 \mathrm{~h}$ post infection, aliquots of $\phi$-A-infected 
Fig. 1 Overview of roseophage-host system. a Potential outcomes of superinfection of Sulfitobacter sp. strain CB-D with $\phi$-A viral particles. b Within the CB-D genome, prophage D is flanked by 15 bp GCrich direct terminal repeats $(a t t B)$, within the $3^{\prime}$ end of a host tRNALeu gene. $\phi$-A harbors a single copy of this sequence (termed attP). c Alignment of $\phi$-A and $\phi$-D genomes and recruitment of environmental virome reads. Purple plots show nucleotide identity between phage genomes (scale ranging from 0 to $100 \%$ ). Open rectangles represent individual ORFs; predicted annotations are provided, where possible. Reads from a North Atlantic, size fractioned virome $(\sim 35 \mathrm{~kb})$ (PRJNA47483) that mapped to either genome are shown directly beneath each phage ORF map. Reads were simultaneously recruited to both of the $\phi$-A and $\phi$-D genomes. Yellow bars represent reads that mapped to either $\phi-\mathrm{A}$ and $\phi-\mathrm{D}$ with equal fidelity $(n=562)$; the distribution of these reads across the two genomes was randomized. Those fragments in black are specific for either $\phi$-A or $\phi$-D $(n=161)$. Refer to Fig. S4 for the full suite of reads recruiting to each phage genome.

Sulfitobacter sp. CB-D cultures were spread onto agar dishes. Fifty randomly selected colonies from each time point were then screened by PCR assay using phagespecific primers. Lysogens PCR positive for $\phi$-A were recovered with relatively high frequency $(\sim 10 \%$ and $\sim 20 \%$ of colonies at 4 h.p.i. and 8 h.p.i., respectively) (Table S2). In addition, this screening method provided evidence of transient polylysogens (PCR positive for both $\phi$-A and $\phi$-D). These putative polylysogens were not stably maintained, reverting to single-lysogens following three or fewer passages on fresh medium.

A representative $\phi$-A positive strain, denoted CB-A, was selected for further study. Genome sequence analysis of CB-A revealed the integration of $\phi$-A at the $a t t B$ site. The $\phi$-D prophage was not present, indicative of a substitution (Fig. 1c). Genome comparisons of CB-A and CB-D show that for all contigs to which $\mathrm{CB}-\mathrm{A}$ Illumina reads mapped to the original CB-D genome, there are no nucleotide differences between these two strains outside of the regions of variation found in the prophages. The genome of CB-D was re-sequenced and showed no difference from the original sequence described in 2014 [36].

\section{Superinfection resistance and differing physiologies of lysogens}

Each of the two lysogens demonstrates resistance to superinfection by the phage particles of the identical genotype: CB-D is resistant to infection with $\phi-\mathrm{D}$ and $\mathrm{CB}-\mathrm{A}$ is resistant to infection with $\phi$-A. Yet each strain is susceptible to lytic infection by the other phage genotype which is accompanied by induction of the resident prophage (Figs. 2c, d and S1). In addition, under routine laboratory cultivation conditions the growth phenotypes of each lysogen were noticeably different. This qualitative assessment prompted quantitative phenotypic characterizations of these strains in liquid and surface-associated growth modes.
In liquid culture, $\mathrm{CB}-\mathrm{D}$ has a shorter generation time and greater maximum cell density than CB-A (Fig. 4a). Doubling times of the CB-D and CB-A lysogens were 75 and $100 \mathrm{~min}$, respectively. In stationary phase, $\mathrm{CB}-\mathrm{A}$ viable counts are half of CB-D $\left(2.51 \times 10^{9}\left[ \pm 7.00 \times 10^{8}\right] \mathrm{CFU} / \mathrm{ml}\right.$ compared with $\left.4.86 \times 10^{9}\left[ \pm 1.48 \times 10^{8}\right] \mathrm{CFU} / \mathrm{ml}\right)$. In contrast, $\mathrm{CB}-\mathrm{A}$ formed more robust biofilms relative to $\mathrm{CB}-\mathrm{D}$ (Fig. 4b). This bulk measurement is supported by confocal microscopy images of CB-A and CB-D biofilms that show substantial differences in biofilm structure (Fig. S2). Sulfitobacter sp. strain CB-A has an average thickness (biomass) of $5.13 \mu \mathrm{m}$, compared with $3.48 \mu \mathrm{m}$ for CB-D. The maximum biomass thickness was also larger for CB-A than CB-D and had a larger range (5.49-13.24 $\mu \mathrm{m}$ compared with $3.57-5.65 \mu \mathrm{m}$, respectively) (Fig. S3 and Table S3).

\section{Titers of free-phage suggest lysogens have different rates of spontaneous prophage induction}

Given the discrepancy in growth dynamics of the two strains, we next determined whether there were quantifiable differences in free-phage titers in CB-A and CB-D cultures. CB-A stationary and mid-log phase cultures yielded $1.63 \times$ $10^{6}\left( \pm 2.08 \times 10^{5}\right) \mathrm{PFU} / \mathrm{ml}$ and $5.2 \times 10^{5}\left( \pm 8.5 \times 10^{4}\right) \mathrm{PFU} /$ $\mathrm{ml}$ respectively. $\mathrm{CB}-\mathrm{D}$ cultures of the same growth states do not yield quantifiable phage using plaque assays, indicating values below the $45 \mathrm{PFU} / \mathrm{ml}$ limit of detection for the assay.

\section{Prophage type determines outcome in head-to- head competition}

The differences in spontaneous induction coupled with the susceptibility of each lysogen to infection by the opposing viral type, which in turn is accompanied by induction of the resident prophage, prompted us to perform competition experiments with these strains. In head-to-head competition (1:1 initial ratio) in broth culture, the ratio of CB-A to CB-D gene copies were 3.26 (range 2.00-4.73) after $24 \mathrm{~h}$ of coculture. The co-cultures were $\sim 90 \%$ and $\sim 65 \%$ lower than typical densities for monocultures of CB-A and CB-D, respectively (Fig. 5a). The number of phage particles present in cell-free filtrates of these mixed cultures were six to one $(\phi-\mathrm{A}: \phi-\mathrm{D}) ; \phi-\mathrm{A}$ and $\phi$-D gene copies were $6.84 \times 10^{9}$ $\left( \pm 2.18 \times 10^{9}\right)$ copies $/ \mathrm{ml}$ and $1.18 \times 10^{9}\left( \pm 0.27 \times 10^{8}\right)$ copies/ $\mathrm{ml}$, respectively. Head-to-head competition assays during growth on a surface showed an opposite response: coculture biofilms had $29 \%$ and $55 \%$ greater biomass than CB-A and CB-D monoculture biofilms, respectively (Fig. 5b). In addition, total $\phi$-D gene copies were 3.4 times as high as $\phi$-A (range 2.7-3.8; Fig. 5b); the biofilm matrix prevented physical separation of cells and unattached viruses, so summed values are presented. 

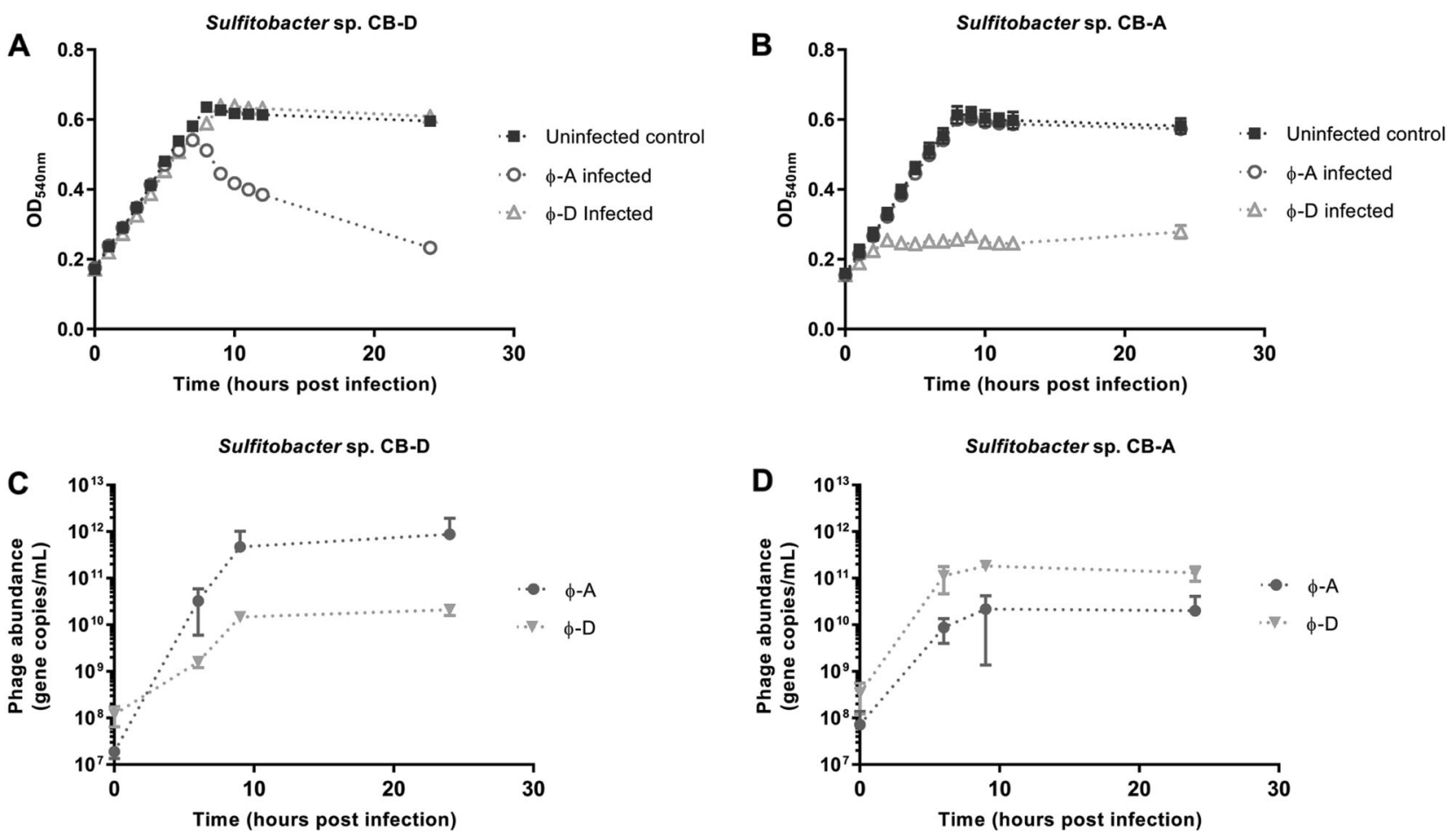

Fig. 2 Sulfitobacter strains CB-D and CB-A susceptibility tests with $\boldsymbol{\phi}$-D and $\boldsymbol{\phi}$-A. a CB-D growth dynamics of cultures superinfected with $\phi$-A (open circles), $\phi$-D (open triangles), compared with uninfected controls (closed squares). b CB-A growth dynamics of cultures superinfected with $\phi$-D (open triangles), $\phi$-A (open circles), compared with uninfected controls (closed squares). Phage gene copies $\mathbf{c}$ during superinfection of CB-D with $\phi-\mathrm{A}$ as shown in panel A and d during

superinfection of CB-A with $\phi$-D as shown in panel B, $\phi$-A gene copies (closed circles) and $\phi$-D gene copies (closed inverted triangles). Phage gene qPCR data represent sum of intracellular and extracellular gene copies. Averages of biological triplicates are reported for all treatments; technical triplicates were run for all qPCR assays. Error bars denote standard deviations and are obscured by the data markers in some instances. Data for this experiment are provided in Tables S4-S7.

Fig. 3 Relative gene expression of CB-D host and phage gene transcripts 3- and 6-h post superinfection with $\phi$-A, relative to non-superinfected controls. a Fold change of host SOS response genes ( $\mathrm{rec} A$ and lexA). b Fold change of $\phi$-A genes, peptidase $($ рер $G)$ and XRE-like transcriptional regulator (xre). c Fold change of prophage $(\phi-D)$ genes, peptidase (pepG), ssDNA break repair protein (rad52), and DNA replication and repair protein $(s s b)$. Significant differences (Student's $t$ tests) are denoted by asterisks $(* p<0.05 ; * * p<0.01$; $* * * p<0.001$; n.s. not significant). Averages of biological and technical triplicates are reported for all treatments and error bars denote standard deviations. Data for this experiment are provided in Table S8.
A
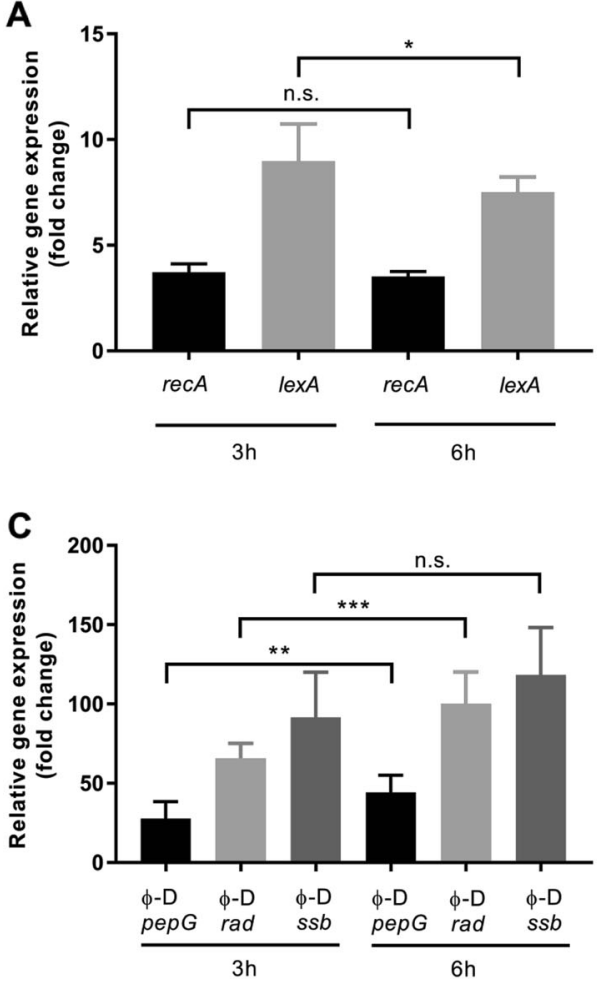

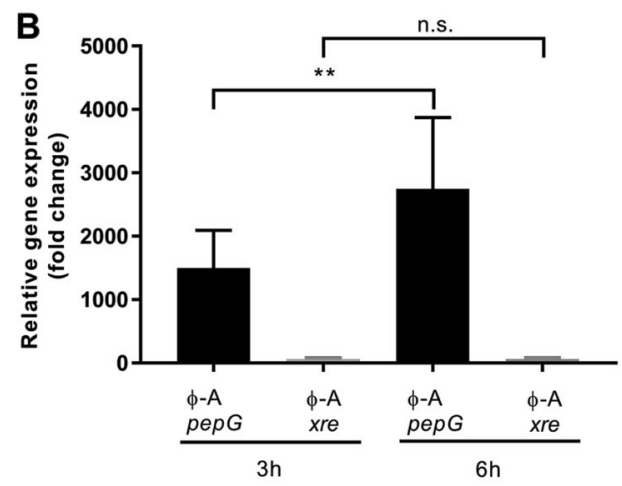




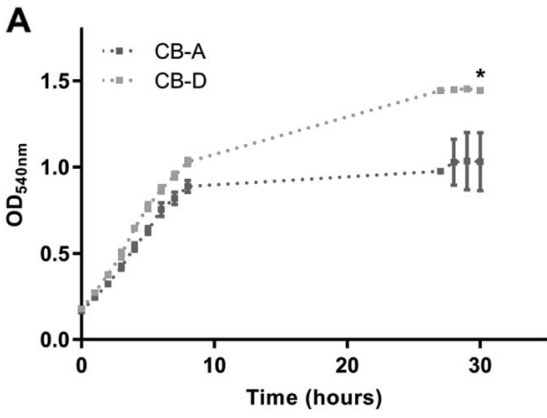

Fig. 4 Physiological characteristics of CB-D and CB-A during different modes of growth. a Growth dynamics of CB-D (light gray) and CB-A (dark gray) in broth cultures and b biofilms at $24 \mathrm{~h}$. Asterisks denote significant differences as determined by Student's $t$

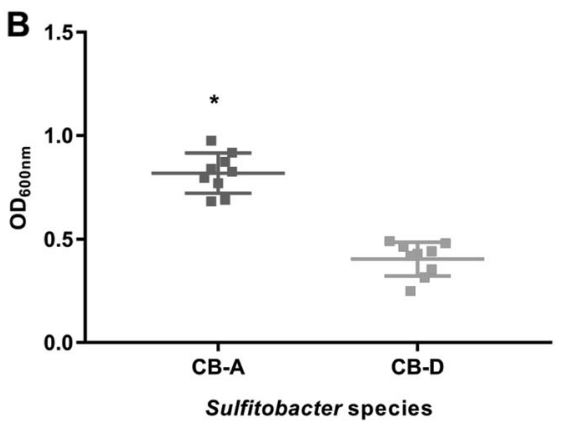

tests $(* p<0.05)$. Averages of biological triplicates and technical triplicates are reported for all treatments. Error bars denote standard deviation and are obscured by the data markers in some instances. All data for this experiment are provided in Tables S9 and S10.
A

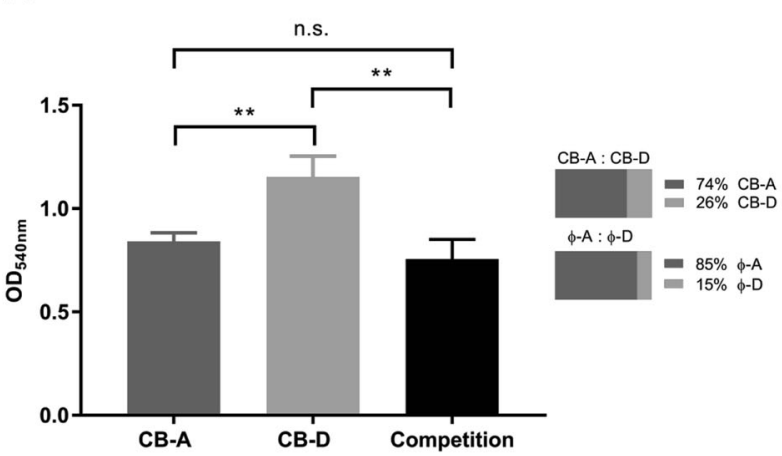

Fig. 5 Head-to-head competition in liquid cultures and biofilms. a Final (24 h) culture densities of broth CB-A monocultures (dark gray), CB-D monocultures (light gray), and co-cultures (black). Horizontal bar graphs depict ratios of CB-D:CB-A and $\phi-A: \phi-D$ in broth cocultures as determined by qPCR. b Final $(24 \mathrm{~h})$ crystal violet biofilm assays for CB-A monocultures (dark gray), CB-D monocultures (light gray), and co-cultures (black) grown as biofilms. qPCR was used to quantify total number of gene copies of CB-D $(+\phi-D)$ :CB-A

\section{Environmental evidence for $\phi-A$ and $\phi-D$}

From the same induced E. huxleyi bloom from which CB-D and $\phi$-A were originally isolated, samples were collected immediately following collapse of the phytoplankton bloom for genetic characterization of viral particles. Of the eight size-selected viral DNA fractions sequenced, reads from two libraries ( $\sim 35$ and $\sim 75 \mathrm{~kb}$ size fractions) mapped to $\phi$-A and $\phi$-D genomes. From the $\sim 35 \mathrm{~kb}$ library $(n=132,133$ reads), 580 individual reads mapped to $\phi$-A and 705 mapped to $\phi$-D (Fig. S4). Of these, 562 reads mapped to homologous regions of both genomes. Unique reads mapped to the divergent regions of the $\phi$-A (18 reads) and $\phi$-D (143 reads) genomes (Fig. 1c). The small numbers of reads, 56 and 86 , from the $75 \mathrm{~kb}$ library $(n=169,279$ reads) that mapped to $\phi$-A and $\phi$-D, respectively, are likely the result of incomplete separation of DNA molecules during PFGE. These data indicate that viral particles from both phage
B

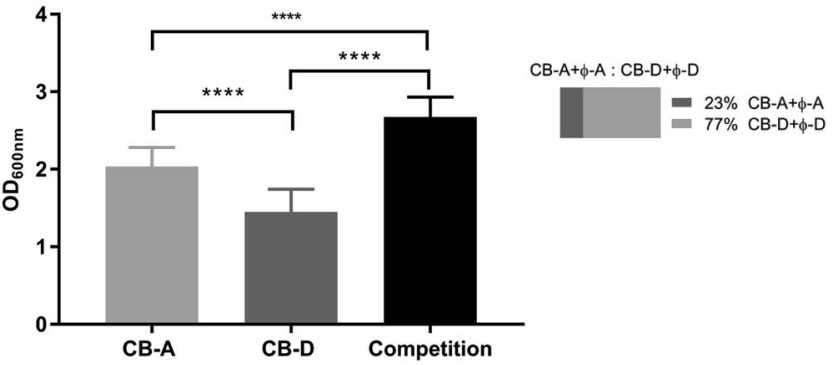

$(+\phi-\mathrm{A})$ in co-culture, as represented in horizontal bar graph. Significant differences (Student's $t$ tests) are denoted by asterisks $\left({ }^{*} p<\right.$ $0.05 ; * * p<0.01 ; * * * p<0.001 ; * * * * p<0.0001 ;$ n.s. not significant). Averages of biological triplicates are reported for all treatments and error bars denote standard deviations. Technical triplicates were run for all qPCR assays and eight technical replicates were run for each biofilm assay. Data for this experiment are provided in Tables S11S13.

types were present, at non-equal abundances, in natural populations.

\section{Discussion}

Viral-mediated lysis of microbial cells in marine systems leads to quantitatively important impacts on food webs and biogeochemical cycles [47]. Yet, our understanding of marine host-virus interactions that give rise to host death, or otherwise influence host fitness, are limited. This is particularly true for temperate viruses of heterotrophic marine bacteria. Here, we describe a new marine host-phage system that advances our understanding of the complex interactions found amongst temperate phages and their susceptible hosts.

Lysogenized bacteria are typically resistant to superinfection, that is secondary infection, by homologous 
phages [reviewed in 48]. $\phi$-A and $\phi$-D are certainly homologous from a genomic perspective, showing a reasonably high degree of nucleotide identity across the full length of their $\sim 40 \mathrm{~kb}$ genomes $(79 \%)$ [36]. Yet, we demonstrate here these lysogens are susceptible to infection by a genetically similar phage. Consistent with the mosaicism commonly observed amongst related phage [49], the genomic differences between $\phi$-A and $\phi$-D are principally restricted to two 4-6 kb regions that appear to encode transcriptional regulators and tail fibers. Tail fiber adsorption to specific bacterial cell-surface receptors is the initial step in successful infection [50,51]. Thus, differences in the primary sequence of the $\phi-\mathrm{A}$ and $\phi$-D tail fiber proteins may indicate distinct cell-surface targets for each of these phages. Furthermore, the putative transcriptional regulatory proteins encoded on $\phi$-A and $\phi$-D map to broad, but distinct, protein families indicating a likelihood for genotypicphenotypic mismatching [i.e., development of immunity groups; e.g., 52-54] leading to the observed symmetrical infection profiles.

Infection of CB-D with $\phi$-A leads to the simultaneous production of $\phi$-A and $\phi$-D, indicative of both lytic infection and prophage induction. While we do not yet know the proteins that mediate the lysogenic-lytic switch in this system, gene expression assays from infected cell populations support quantitative measurements of phage abundance. A putative peptidase ( $е e p G)$ encoded by $\phi$-A is upregulated during superinfection relative to nonsuperinfected CB-D controls. Similarly, upregulation of the CB-D host genes recA and lexA indicates activation of the global SOS response, which has been shown to mediate the lysogenic to lytic switch in various bacteria [e.g., Salmonella enterica, Escherichia coli, and Pseudomonas aeruginosa; reviewed in 55-57]. Indeed, superinfection by other phages has been shown to be a biotic factor influencing prophage induction, presumably through induction of the SOS response $[58,59]$. In contrast, a $\phi$-A putative transcriptional regulator (xre-like), is below the limit of detection, perhaps suggesting a role for this gene's product in suppression of phage lytic genes during the lysogenic state. As the $\phi-\mathrm{A}$ and $\phi$-D encoded transcriptional regulators lack conserved catalytic domains common to well characterized phage repressors, these proteins may be valuable targets for future studies aimed at deciphering the lysogenic-lytic switch in these Sulfitobacter-phage pairs. An aspect of lytic activation of prophages in response to superinfection that has not been explored in our, or other systems, is whether lytic infection and prophage induction occur simultaneously in an individual cell or within distinct subpopulations of cells, one undergoing lytic infection by an exogenous phage and the other undergoing lytic activation of a previously quiescent prophage. It is possible that a subpopulation superinfected with one phage could communicate with non-superinfected counterparts, thus initiating a lytic induction, a phenomenon that has only recently been reported for a Bacillus phage [60].

In addition to a mixed infection resulting in the production of both $\phi$-A and $\phi$-D viral particles, infection of CB-D with $\phi$-A also yields new lysogens in which the prophage appears to have been replaced by the superinfecting phage. The mechanism whereby this presumptive substitution occurs is not yet clear, but several possibilities exist. It could have been achieved through homologous recombination between the phage genomes, an oft-cited mechanism of viral evolution [61-63]. Alternatively, eviction of the prophage followed by integration of the $\phi$-A genome could have led to the production of CB-A variants. While an intriguing possibility, there is presently little evidence in the literature to suggest such interactions occur amongst phages. A third possibility is that a subpopulation of host cells in our cultures lack a prophage, freeing the attachment site for integration. Using qPCR across the integration site, we estimate that a small subpopulation (ranging from 0.02 to $0.08 \%$ of Sulfitobacter sp. CB-D cultures) lack a prophage at the $a t t B$ site (data not shown). Such individual cells would have increased susceptibility to lysogeny by $\phi$-A invasion. Finally, integration of both prophages in tandem could result in the establishment of transient polylysogens. Due to an intrinsic instability arising from the high degree of nucleotide identity between the two phages, such presumed polylysogenic events might be expected to readily revert to a single phage type. Regardless of the apparent replacement mechanism, the relatively high frequency with which new lysogens are recovered from superinfections suggests either genotypic switching is prevalent with this two-phage-one-host system or that onehost-phage pair displays higher fitness than the other in a given environmental context.

Our data indicate a competitive interaction between the two host-phage pairs based on a fundamental difference in their lysogenic-lytic switches. One manifestation of these differences is altered frequencies of SPI that influence growth dynamics when the strains are cultivated planktonically and as biofilms. Rates of SPI are anticipated to be the combined result of stochasticity in gene expression (genetic noise) and induction of the SOS response. It has been observed that either a drop in phage repressor protein levels below a given threshold concentration or sporadic expression of integrase genes may initiate the lytic cycle [64]. Noise is pervasive in gene regulatory networks and can provide selective advantage to populations by increasing phenotypic heterogeneity within individual species and complex microbial communities [reviewed in 6]. Thus, prophages may exploit genetic noise to modulate the frequency of spontaneous activation. In contrast, the apparent instability of the lysogenic state in CB-A may indicate a 
nonoptimal pairing between host and phage. A recent example with nearly genetically identical marine Bacteriodetes strains reveals variation in infection efficiency across strains challenged with the same phage [65]. Regardless of the underlying mechanism(s) that give rise to the observed variation SPI in these two lysogens, this variation directly influences interactions amongst them.

Until recently, SPI was largely considered detrimental as some fraction of the cells is continuously lost by phageinduced lysis. However, benefits of SPI on bacterial fitness are now recognized, and include the release of extracellular DNA, which facilitates and enhances biofilm formation $[6,66]$, consistent with our findings. It has also been suggested that SPI dictates the maintenance and propagation of lysogeny in S. enterica, which is important for the evolution and diversity of host populations [67]. Relevant to our study is the notion that lysogens may use SPI as a form of specialized weaponry against susceptible cell types, whether they be nonlysogenized variants of the same strain or different species [14]. As an ecological adaptation to physically structured environments, temperate phages are theorized to enhance the fitness of their hosts through killing of susceptible competitors [68, 69]. Empirical studies support this proposed form of allelopathy. For example, $S$. enterica studies demonstrate selective eradication of nonimmune hosts in mixed populations as a means of a competing strategy by Gifsy 2 lysogenized strains [67]. Rat model competition studies show that $P$. aeruginosa strains lysogenized by Liverpool Epidemic Strain prophages use the phages as anti-competitor weapons against phagesusceptible $P$. aeruginosa populations in a chronic lung infection model [70]. Studies using E. coli MG1655 lysogenized with $\lambda$ reveal the competitive nature of this type of inaction is anticipated to be limited, as lysogenization of susceptible hosts ultimately diminishes nonlysogenized "competitors" [71]. Finally, in a more complicated scenario involving members of the microbiome of the freshwater metazoan, Hydra vulgaris, one microbiome member, a Curvibacter species, possesses an inducible prophage that lytically infects another microbiome member, a Duganella strain. Mathematical modeling predicts this interaction may modulate competition amongst microbiome members [72].

Our system proposes a new element to this type of interaction: the reciprocal attack by genetically similar phages that share an integration site in a common host. Head-to-head competition experiments between CB-A and CB-D indicate different fates depending upon mode of bacterial growth: planktonic or biofilm, two modes in which Roseobacters, in general, and Sulfitobacters, in particular, thrive in nature $[73,74]$. We acknowledge these laboratorybased experiments are unlikely to be a faithful reflection of the interactions these host-phage pairs would display in the wild, where, amongst other factors, nutrients and cell abundances would be lower and community complexity higher, respectively. However, genetic signatures identified in a virome collected at the terminus of the phytoplankton bloom in the North Atlantic from which the original host and phage were isolated supports the co-existence of both phage particles in natural waters, at nonequivalent abundances (i.e., $\phi$-D particles are better represented than $\phi$-A). At the time of sample collection, phytoplankton debris was elevated in this system, as were Roseobacter abundances [75]. The overrepresentation of $\phi$-D relative to $\phi$-A appears consistent with our laboratory co-culture biofilm experiments in which the $\phi$-D type prevails.

The lab and field data presented here demonstrate that both phage types can occur in mixed populations and indicate the competitiveness of a given host-virus pair is niche specific. Thus, the maintenance of both phage types within a population may be advantageous to a given host over multiple generations and across marine landscapes. Indeed, we might consider these discrete host-phage populations as analogous to bacterial populations that exhibit phase variation. Phase variation has been described as an interchange between physiological "states", and is exemplified by the production of antigenic components, $\mathrm{H} 1$ and $\mathrm{H} 2$, in motile and nonmotile strains of $S$. enterica (formerly known as Salmonella choleraesuis) that allow the bacterium to rapidly adapt to shifting environmental conditions [76]. Why co-cultures of CB-A and CB-D have divergent outcomes depending upon growth mode (planktonic vs. biofilm) is presently unknown. However, given that integrated viral genes within a lysogen can confer a myriad of phenotypic and fitness effects (e.g., increased antibiotic resistance, biofilm formation ability, altered growth dynamics, metabolic reprograming $[2,68,77,78]$ ), it is intriguing to consider that the physiological distinctions displayed by CB-A and CB-D extend beyond variation in their lysogenic-lytic switch mechanisms. Important next steps in this research also include development of tools to allow the tracking of individual cells and viral particles to better elucidate the dynamics of each of the players in this complex interaction.

Lysogeny is widespread in nature and has recently received considerable attention in the context of marine systems where focus has been on elucidation of the environmental factors that drive temperate phage into either a lytic or lysogenic state [e.g., 27, 28]. Our work reveals the importance of intrinsic factors in influencing host-phage interactions and highlights the value of considering states that lie between the bilateral viewpoint of wholesale lysogeny or rampant lysis within a population. Characterization of a two-phage-one-host model system suggests new mechanisms of microbial competition and cooperation in which host-phage pairs may form coalitions to challenge one another. The outcomes of these "challenges" appear 
context dependent, and may to lead to niche-specific quasistate equilibria. The extent to which these cooperative behaviors are influenced by other environmental factors (e.g., nutrients, temperature, and host abundance), include additional lysogen-state phenotypic differences and/or modulate community composition remains to be determined. Another open question is the prevalence of these types of host-phage interactions in marine systems. Modern abilities to sequence the genomic content of individual cells and free viruses in a culture-independent manner (e.g., [79, 80]) should facilitate studies aimed at determining whether interactions such as those described here occur in nature. Given the extent of genetic microheterogeneity present in both marine microbial and viral communities, we predict these types of coalitions represent an overlooked component of host-phage interactions in the seas, particularly in environments where the chemical and physical properties undergo dramatic and rapid change (e.g., phytoplankton blooms).

Acknowledgements The authors wish to thank Mary Hadden and Yi Ting Jiang for the generation of Sulfitobacter sp. strain CB-A. We also thank Mary Hadden for assistance with qPCR. We are indebted to Dr John Dunlap for assistance with confocal microscopy. This research was supported by the National Science Foundation (NSF OCE\#1737237 to AB).

\section{Compliance with ethical standards}

Conflict of interest The authors declare that they have no conflict of interest.

Publisher's note Springer Nature remains neutral with regard to jurisdictional claims in published maps and institutional affiliations.

Open Access This article is licensed under a Creative Commons Attribution 4.0 International License, which permits use, sharing, adaptation, distribution and reproduction in any medium or format, as long as you give appropriate credit to the original author(s) and the source, provide a link to the Creative Commons license, and indicate if changes were made. The images or other third party material in this article are included in the article's Creative Commons license, unless indicated otherwise in a credit line to the material. If material is not included in the article's Creative Commons license and your intended use is not permitted by statutory regulation or exceeds the permitted use, you will need to obtain permission directly from the copyright holder. To view a copy of this license, visit http://creativecommons. org/licenses/by/4.0/.

\section{References}

1. Brussow H, Canchaya C, Hardt WD. Phages and the evolution of bacterial pathogens: from genomic rearrangements to lysogenic conversion. Microbiol Mol Biol Rev. 2004;68:560-602.

2. Bondy-Denomy J, Davidson AR. When a virus is not a parasite: the beneficial effects of prophages on bacterial fitness. J Microbiol. 2014;52:235-42.

3. Paul JH. Prophages in marine bacteria: dangerous molecular time bombs or the key to survival in the seas? ISME J. 2008;2:579-89.
4. Canchaya C, Fournous G, Chibani-Chennoufi S, Dillmann ML, Brussow H. Phage as agents of lateral gene transfer. Curr Opin Microbiol. 2003;6:417-24.

5. Feiner R, Argov T, Rabinovich L, Sigal N, Borovok I, Herskovits AA. A new perspective on lysogeny: prophages as active regulatory switches of bacteria. Nat Rev Microbiol. 2015;13:641-50.

6. Nanda AM, Thormann K, Frunzke J. Impact of spontaneous prophage induction on the fitness of bacterial populations and host-microbe interactions. J Bacteriol. 2015;197:410-9.

7. Touchon M, Bernheim A, Rocha EPC. Genetic and life-history traits associated with the distribution of prophages in bacteria. ISME J. 2016;10:2744-54.

8. Fortier LC, Sekulovic O. Importance of prophages to evolution and virulence of bacterial pathogens. Virulence. 2013;4:354-65.

9. Helfrich S, Pfeifer E, Kramer C, Sachs CC, Wiechert W, Kohlheyer D, et al. Live cell imaging of SOS and prophage dynamics in isogenic bacterial populations. Mol Microbiol. 2015;98:636-50.

10. Pennington JM, Rosenberg SM. Spontaneous DNA breakage in single living Escherichia coli cells. Nat Genet. 2007;39:797-802.

11. Simmons LA, Goranov AI, Kobayashi H, Davies BW, Yuan DS, Grossman $\mathrm{AD}$, et al. Comparison of responses to double-strand breaks double-strand breaks between Escherichia coli and Bacillus subtilis reveals different requirements for SOS inductions. J Bacteriol. 2009;191:1152.

12. Kamenšek S, Podlesek Z, Gillor O, Zgur-Bertok D. Genes regulated by the Escherichia coli SOS repressor LexA exhibit heterogeneous expression. BMC Microbiol. 2010;10:283.

13. Nanda AM, Heyer A, Krämer C, Grünberger A, Kohlheyer D, Frunzke J. Analysis of SOS-induced spontaneous prophage induction in Corynebacterium glutamicum at the single-cell level. J Bacteriol. 2014;196:180.

14. Harrison E, Brockhurst MA. Ecological and evolutionary benefits of temperate phage: what does or doesn't kill you makes you stronger. BioEssays. 2017;39:1700112.

15. Leitet C, Riemann L, Hagstrom A. Plasmids and prophages in Baltic Sea bacterioplankton isolates. J Mar Biol Assoc UK. 2006;86:567-75.

16. Stopar D, Cerne A, Zigman M, Poljsak-Prijatelj M, Turk V. Viral abundance and a high proportion of lysogens suggest that viruses are important members of the microbial community in the Gulf of Trieste. Microb Ecol. 2004;47:1-8.

17. Hurwitz BL, Westveld AH, Brum JR, Sullivan MB. Modeling ecological drivers in marine viral communities using comparative metagenomics and network analyses. Proc Natl Acad Sci USA. 2014;111:10714-9.

18. Duhaime MB, Deng L, Poulos BT, Sullivan MB. Towards quantitative metagenomics of wild viruses and other ultra-low concentration DNA samples: a rigorous assessment and optimization of the linker amplification method. Environ Microbiol. 2012;14:2526-37.

19. Brum JR, Hurwitz BL, Schofield O, Ducklow HW, Sullivan MB. Seasonal time bombs: dominant temperate viruses affect Southern Ocean microbial dynamics. ISME J. 2016;10:437-49.

20. Payet JP, Suttle CA. To kill or not to kill: the balance between lytic and lysogenic viral infection is driven by trophic status. Limnol Oceanogr. 2013;58:465-74.

21. Williamson SJ, Houchin LA, McDaniel L, Paul JH. Seasonal variation in lysogeny as depicted by prophage induction in Tampa Bay, Florida. Appl Environ Microbiol. 2002;68:4307-14.

22. Jiang SC, Paul JH. Significance of lysogeny in the marine environment: Studies with isolates and a model of lysogenic phage production. Microb Ecol. 1998;35:235-43.

23. Weinbauer MG, Suttle CA. Lysogeny and prophage induction in coastal and offshore bacterial communities. Aquat Microb Ecol. 1999; 18:217-25. 
24. Thingstad TF, Lignell R. Theoretical models for the control of bacterial growth rate, abundance, diversity and carbon demand. Aquat Microb Ecol. 1997;13:19-27.

25. Luo E, Aylward FO, Mende DR, DeLong EF. Bacteriophage distributions and temporal variability in the Ocean's Interior. Mbio. 2017;8:1-13.

26. Giovannoni S, Temperton B, Zhao YL. SAR11 viruses and defensive host strains reply. Nature. 2013;499:E4-5.

27. Knowles B, Silveira CB, Bailey BA, Barott K, Cantu VA, CobianGuemes AG, et al. Lytic to temperate switching of viral communities. Nature. 2016;531:466-70.

28. Weitz JS, Beckett SJ, Brum JR, Cael BB, Dushoff J. Lysis, lysogeny and virus-microbe ratios. Nature. 2017;549:E1-3.

29. Knowles B, Rohwer F. Knowles \& Rohwer reply. Nature. 2017;549:E3-4.

30. Billerbeck S, Wemheuer B, Voget S, Poehlein A, Giebel HA, Brinkhoff $\mathrm{T}$, et al. Biogeography and environmental genomics of the Roseobacter-affiliated pelagic CHAB-I-5 lineage. Nat Microbiol. 2016;1:1-8.

31. Buchan A, Gonzalez JM, Moran MA. Overview of the marine Roseobacter lineage. Appl Environ Microbiol. 2005;71:5665-77.

32. Slightom RN, Buchan A. Surface colonization by marine Roseobacters: integrating genotype and phenotype. Appl Environ Microbiol. 2009;75:6027-37.

33. Zhao YL, Wang K, Ackermann HW, Halden RU, Jiao NZ, Chen F. Searching for a "Hidden" prophage in a Marine Bacterium. Appl Environ Microbiol. 2010;76:589-95.

34. Chen F, Wang K, Stewart J, Belas R. Induction of multiple prophages from a marine bacterium: a genomic approach. Appl Environ Microbiol. 2006;72:4995-5001.

35. Ankrah NYD, Budinoff CR, Wilson WH, Wilhelm SW, Buchan A. Genome sequences of two temperate phages, ФCB2047-A and ФCB2047-C, infecting Sulfitobacter sp. Strain 2047. Genome Announc. 2014;2:1-2.

36. Ankrah NYD, Lane T, Budinoff CR, Hadden MK, Buchan A. Draft genome sequence of Sulfitobacter sp. CB2047, a member of the roseobacter clade of marine bacteria, isolated from an Emiliania huxleyi Bloom. Genome Announc. 2014;2:1-2.

37. Budinoff CR, Hollibaugh JT. Ecophysiology of a mono lake picocyanobacterium. Limnol Oceanogr. 2007;52:2484-95.

38. Ankrah NYD. Elucidating the impact of roseophage on roseobacter metabolism and marine nutrient cycles [Doctoral dissertation]. Knoxville: The University of Tennessee; 2015.

39. Kropinski AM, Mazzocco A, Waddell TE, Lingohr E, Johnson RP. Enumeration of bacteriophages by double agar overlay plaque assay. In: Clokie MRJ, Kropinski AM, editors. Bacteriophages: methods and protocols, Volume 1: isolation, characterization, and interactions. Totowa, NJ: Humana Press; 2009. p. 69-76.

40. Nieto PA, Covarrubias PC, Jedlicki E, Holmes DS, Quatrini R. Selection and evaluation of reference genes for improved interrogation of microbial transcriptomes: case study with the extremophile Acidithiobacillus ferrooxidans. BMC Mol Biol. 2009; 10:63.

41. Green MR. In: Sambrook J, editor. Molecular cloning: a laboratory manual. 4th ed. Cold Spring Harbor Laboratory Press: NY; 2012.

42. Cude WN, Prevatte CW, Hadden MK, May AL, Smith RT, Swain CL, et al. Phaeobacter sp strain Y4I utilizes two separate cell-tocell communication systems to regulate production of the antimicrobial indigoidine. Appl Environ Microbiol. 2015;81:1417-25.

43. Pagarete A, Le Corguille G, Tiwari B, Ogata H, de Vargas C, Wilson $\mathrm{WH}$, et al. Unveiling the transcriptional features associated with coccolithovirus infection of natural Emiliania huxleyi blooms. FEMS Microbiol Ecol. 2011;78:555-64.

44. Hellemans J, Mortier G, De Paepe A, Speleman F, Vandesompele J. qBase relative quantification framework and software for management and automated analysis of real-time quantitative PCR data. Genome Biol. 2007;8:R19.

45. Mahadevan P, King JF, Seto D. CGUG: in silico proteome and genome parsing tool for the determination of "core" and unique genes in the analysis of genomes up to ca. 1.9 Mb. BMC Res Notes. 2009;2:168.

46. Fouts DE. Phage_Finder: automated identification and classification of prophage regions in complete bacterial genome sequences. Nucleic Acids Res. 2006;34:5839-51.

47. Fuhrman JA. Marine viruses and their biogeochemical and ecological effects. Nature. 1999;399:541-8.

48. Weinbauer MG. Ecology of prokaryotic viruses. FEMS Microbiol Rev. 2004;28:127-81.

49. Dorscht J, Klumpp J, Bielmann R, Schmelcher M, Born Y, Zimmer M, et al. Comparative Genome analysis of Listeria bacteriophages reveals extensive mosaicism, programmed translational frameshifting, and a novel prophage insertion site. J Bacteriol. 2009;191:7206.

50. Randall-Hazelbauer L, Schwartz M. Isolation of the bacteriophage lambda receptor from Escherichia coli. J Bacteriol. 1973;116:1436-46.

51. Wang J, Hofnung M, Charbit A. The C-terminal portion of the tail fiber protein of bacteriophage lambda is responsible for binding to LamB, its receptor at the surface of Escherichia coli K-12. J Bacteriol. 2000;182:508.

52. Mavrich TN, Hatfull GF. Evolution of superinfection immunity in cluster A mycobacteriophages. mBio. 2019;10:e00971-19.

53. Degnan PH, Michalowski CB, Babić AC, Cordes MHJ, Little JW. Conservation and diversity in the immunity regions of wild phages with the immunity specificity of phage $\lambda$. Mol Microbiol. 2007;64:232-44.

54. Berngruber TW, Weissing FJ, Gandon S. Inhibition of superinfection and the evolution of viral latency. $\mathrm{J}$ Virol. 2010;84:10200.

55. Butala M, Žgur-Bertok D, Busby SJW. The bacterial LexA transcriptional repressor. Cell Mol Life Sci. 2008;66:82.

56. Campoy S, Hervàs A, Busquets N, Erill I, Teixidó L, Barbé J. Induction of the SOS response by bacteriophage lytic development in Salmonella enterica. Virology. 2006;351:360-7.

57. Cirz RT, O’Neill BM, Hammond JA, Head SR, Romesberg FE. Defining the Pseudomonas aeruginosa SOS response and its role in the global response to the antibiotic ciprofloxacin. J Bacteriol. 2006;188:7101-10.

58. Campos J, Martinez E, Suzarte E, Rodriguez BL, Marrero K, Silva Y, et al. VGJ phi, a novel filamentous phage of Vibrio cholerae, integrates into the same chromosomal site as CTX phi. J Bacteriol. 2003;185:5685-96.

59. Espeland EM, Lipp EK, Huq A, Colwell RR. Polylysogeny and prophage induction by secondary infection in Vibrio cholerae. Environ Microbiol. 2004;6:760-3.

60. Erez Z, Steinberger-Levy I, Shamir M, Doron S, Stokar-Avihail A, Peleg Y, et al. Communication between viruses guides lysislysogeny decisions. Nature. 2017;541:488-93.

61. Clark AJ, Inwood W, Cloutier T, Dhillon TS. Nucleotide sequence of coliphage HK620 and the evolution of lambdoid phages1 1 (Edited by) M Gottesman. J Mol Biol. 2001;311: 657-79.

62. De Paepe M, Hutinet G, Son O, Amarir-Bouhram J, Schbath S, Petit M-A. Temperate phages acquire DNA from defective prophages by relaxed homologous recombination: the role of Rad52like recombinases. PLoS Genet. 2014;10:e1004181.

63. Bouchard JD, Moineau S. Homologous recombination between a lactococcal bacteriophage and the chromosome of its host strain. Virology. 2000;270:65-75.

64. Broussard GW, Oldfield LM, Villanueva VM, Lunt BL, Shine EE, Hatfull GF. Integration-dependent bacteriophage immunity 
provides insights into the evolution of genetic switches. Mol Cell. 2013;49:237-48.

65. Howard-Varona C, Roux S, Dore H, Solonenko NE, Holmfeldt K, Markillie LM, et al. Regulation of infection efficiency in a globally abundant marine Bacteriodetes virus. ISME J. 2017;11:284-95.

66. Carrolo M, Frias MJ, Pinto FR, Melo-Cristino J, Ramirez M. Prophage spontaneous activation promotes DNA release enhancing biofilm formation in Streptococcus pneumoniae. PLoS ONE. 2010;5:1-10.

67. Bossi L, Fuentes JA, Mora G, Figueroa-Bossi N. Prophage contribution to bacterial population dynamics. J Bacteriol. 2003;185:6467-71.

68. Stewart FM, Levin BR. The population biology of bacterial viruses: why be temperate. Theor Popul Biol. 1984;26:93-117.

69. Cortes MG, Krog J, Balázsi G. Optimality of the spontaneous prophage induction rate. J Theor Biol. 2019;483:110005.

70. Davies EV, James CE, Kukavica-Ibrulj I, Levesque RC, Brockhurst MA, Winstanley C. Temperate phages enhance pathogen fitness in chronic lung infection. ISME J. 2016;10:2553-5.

71. Gama JA, Reis AM, Domingues I, Mendes-Soares H, Matos AM, Dionisio F. Temperate bacterial viruses as double-edged swords in bacterial warfare. PLoS ONE. 2013;8:1-9.

72. Li XY, Lachnit T, Fraune S, Bosch TCG, Traulsen A, Sieber M. Temperate phages as self-replicating weapons in bacterial competition. J R Soc Interface. 2017;14:1-7.
73. Buchan A, LeCleir GR, Gulvik CA, Gonzalez JM. Master recyclers: features and functions of bacteria associated with phytoplankton blooms. Nat Rev Microbiol. 2014;12:686-98.

74. LeCleir GR, DeBruyn JM, Maas EW, Boyd PW, Wilhelm SW. Temporal changes in particle-associated microbial communities after interception by nonlethal sediment traps. FEMS Microbiol Ecol. 2014;87:153-63.

75. Budinoff CR. Diversity and activity of roseobacters and roseophage [Doctoral dissertation]. Knoxville: The University of Tennessee; 2012.

76. Lederberg J, Iino T. Phase variation in Salmonella. Genetics. 1956;41:743-57.

77. Wang XX, Kim Y, Ma Q, Hong SH, Pokusaeva K, Sturino JM, et al. Cryptic prophages help bacteria cope with adverse environments. Nat Commun. 2010;1:1-9.

78. Terzi M, Levinthal C. Effects of $\lambda$-phage infection on bacterial synthesis. J Mol Biol. 1967;26:525-35.

79. Labonté JM, Swan BK, Poulos B, Luo H, Koren S, Hallam SJ, et al. Single-cell genomics-based analysis of virus-host interactions in marine surface bacterioplankton. ISME J. 2015;9: 2386-99.

80. Roux S, Brum JR, Dutilh BE, Sunagawa S, Duhaime MB, Loy A, et al. Ecogenomics and potential biogeochemical impacts of globally abundant ocean viruses. Nature. 2016;537:689-93. 